\title{
ANALISIS RESPON GURU TERHADAP PELATIHAN PENGELOLAAN EMOSI ANAK USIA DINI
}

\author{
Tien Asmara Palintan \\ Pendidikan Islam Anak Usia Dini, Institut Agama Islam Negeri (IAIN) Parepare
}

\begin{abstract}
:
The problem of managing emotions in early childhood that the researchers found was that early childhood teachers found it difficult to develop the emotional aspects of children. Early Childhood Emotion Management Training is used as an intervention in helping PAUD teachers to develop emotional aspects of early childhood. The subjects in this training consisted of 31 PAUD teachers. This study refers to an experimental approach with the OneShot Case Study design. Subjects were given treatment in the form of Early Childhood Emotion Management Training and then the results were observed. This training was held three times, with a duration of 120 minutes for each meeting. Validation of the Teacher Response Questionnaire (ARG) obtained a value of $x=3.64$, including the very valid category. The empirical validation of the study stated that $98 \%$ of research subjects stated that the teacher's response was very good (positive) towards the implementation of early childhood emotional management training.
\end{abstract}

Keywords: teacher response, training, emotion.

\begin{abstract}
Abstrak:
Penelitian ini bertujuan untuk mengetahui respon guru Pendidikan Anak Usia Dini (PAUD) terhadap pelaksanaan pelatihan pengelolaan emosi pada anak usia dini. Permasalahan pengelolaan emosi pada anak usia dini yang ditemukan peneliti adalah guru PAUD merasa kesulitan dalam mengembangkan aspek emosi anak. Pelatihan pengelolaan emosi anak usia dini bertujuan sebagai intervensi dalam membantu guru PAUD untuk mengembangkan aspek emosi anak usia dini. Subjek dalam pelatihan ini terdiri dari 31 orang guru PAUD. Penelitian ini mengacu pada pendekatan eksperimen dengan desain One-Shot Case Study. Subjek diberi treatment dalam bentuk Pelatihan Pengelolaan Emosi Anak Usia Dini dan selanjutnya diobservasi hasilnya. Pelatihan ini terlaksana tiga kali, dengan durasi 120 menit untuk setiap pertemuan. Validasi Angket Respon Guru (ARG) memperoleh nilai $x=3,64$, termasuk kategori sangat valid. Validasi empirik penelitian menyatakan bahwa $98 \%$ subjek penelitian menyatakan respon guru sangat baik (positif) terhadap pelaksanaan pelatihan pengelolaan emosi anak usia dini.
\end{abstract}

Kata Kunci: respon guru, pelatihan, emosi 


\section{PENDAHULUAN}

Guru PAUD memiliki peran sebagai pelaksana pembelajaran yang bertanggung jawab untuk mendidik dan mengembangkan potensi peserta didik. Guru diharapkan mampu menjadi fasilitator, motivator, pengamat, pendamai dan pengasuh. Namun sayangnya, tidak semua guru mampu melaksanakan berbagai tugas mulia tersebut. Kurangnyanya pengembangan potensi guru diasumsikan menjadi penyebab mengapa guru kurang mampu menjalankan perannya dengan baik.

Pada dunia pendidikan, guru memiliki peran penting dalam memacu keberhasilan peserta didiknya. Wijaya (2018) menyatakan bahwa guru adalah figur sentral dalam penyelenggaraan pendidikan. Ditangan gurulah pendidikan secara profesional dapat terlaksana, betapa pun banyaknya biaya dan baiknya kurikulum yang telah dirancang para ahli. Tanggung jawab yang dimiliki guru berdampak pada keberhasilannya dalam mengemban tugas.

Peran penting guru anak usia dini terlihat pada proses interaksi dengan peserta didik, mengasuh anak, menyediakan sarana, mengelola stress, merencanakan, membimbing dan memelihara, serta memberikan pengayaan dan pengembangan pembelajaran (Fizia, 2020). Berbagai kompetensi harus dimiliki oleh guru PAUD sebagai tenaga professional. Meliputi, perencanaan pelaksanaan, evaluasi program, memberi bimbingan dan motivasi serta menyiapkan fasiltas untuk mengasuh anak didik (Jalal, 2017).

Berkaitan dengan pemaparan di atas, maka upaya guru untuk membantu mengelola aspek emosi anak usia dini sangatlah diperlukan. Mengingat masa usia dini adalah periode emas (golden age) sehingga sangat baik untuk memaksimalkan stimulasi pada setiap aspek perkembangannya. Guru hendaknya mampu memaksimalkan periode sensitif pada anak, sehingga rasa ingin tahu dan kepekaan yang tinggi pada anak dapat terfasilitasi dengan baik. Bimbingan ataupun pelatihan diberikan kepada guru PAUD agar mereka mendapatkan pemahaman yang baik dalam mengelola aspek emosi anak. Karena guru merupakan salah satu unsur utama dari proses pembelajaran. Kompetensi profesi yang dimiliki guru PAUD merupakan potensi besar yang diharapkan mampu menjadikan guru menguasai keahlian tertentu. Seorang guru PAUD diharapkan mampu membuat dokumentasi berbagai proses pertumbuhan dan perkembangan peserta didik, merencanakan pembelajaran yang menyenangkan, merancang kegiatan yang menarik dan menantang, serta dapat melakukan asesmen untuk berbagai kegiatan bermain dan belajar anak (Maryatun, 2016). Maka pendidikan dan pelatihan dipandang perlu untuk diberikan kepada guru PAUD, karena predikatnya sebagai tombak pelaksana pendidikan pada jalur non formal.

Sudrajat (2008) mengemukakan urgensi pelatihan bagi guru PAUD antara lain: 1) mengembangkan kemampuan problem solving guru; 2) meningkatkan etos kerja guru; 3) mengembangkan decision making (pengambilan keputusan) guru; 4) memotivasi guru menjadi lebih berani untuk menghadapi tantangan; 5) meningkatkan kemandirian guru. Berdasarkan penjelasan tersebut, maka penulis tertarik untuk menganalisis respon guru terhadap model pelatihan pengelolaan emosi anak usia dini. Mengingat faktor emosi begitu penting dalam menentukan keberhasilan belajar anak, sehingga guru perlu memahami emosi peserta didik. Pembelajaran akan lebih bermakna apabila guru mampu memahami 
emosi peserta didik. Sehingga jalinan emosional akan terbangun, $g$ angguan belajar dapat teratasi, dan siswa dapat menikmati pembelajaran yang mneyenangkan.

\section{METODOLOGI}

Pendekatan yang digunakan pada penelitian ini mengacu adalah eksperimen. Sugiyono (2019:107) mengemukakan bahwa penelitian eksperimen digunakan apabila peneliti ingin melakukan percobaan untuk mencari pengaruh variable independent atau perlakuan tertentu terhadap variabel dependen dalm kondisi yang terkendalikan. Penelitian eksperimen ini dispesifikkan pada desain One-Shot Case Study.. Sekelompok guru PAUD diberi pelatihan terkait pengelolaan Emosi Anak Usia Dini dan selanjutnya diobservasi hasilnya.

Subyek penelitian adalah 31 orang guru PAUD. Meliputi 9 orang guru dari TK Melati Binaan PKK Kabupaten Gowa sebagai fokus penelitian, dan 22 orang guru perwakilan dari Ikatan Guru Taman Kanak-kanak Indonesia (IGTKI) Kabupaten Gowa Sulawesi Selatan sebagai subyek uji coba pelatihan. Guru-guru tersebut berasal dari beberapa lembaga PAUD yang ada di Kabupaten Gowa. Adapun karakteristik subjek penelitian ini antara lain:

1. Guru dari siswa (i) usia dini (berusia 5-6 tahun atau kelompok B).

2. Belum pernah mengikuti kegiatan pelatihan pengelolaan emosi anak usia dini.

3. Telah memiliki pengalaman mengajar anak usia dini minimal 1 tahun.

4. Latar belakang pendidikan minimal S1.

5. Bersedia mengikuti program pelatihan pengelolaan emosi anak usia dini.

Peneliti menggunakan Angket Respon Guru (ARG) sebagai pengumpul data. Sebagai subjek penelitian, guru diharapkan mampu memberikan informasi tentang penilaian umum model pelatihan serta dampaknya bagi perkembangan anak usia dini. Guru juga memberikan respon terhadap persetujuan pengembangan model pelatihan dan respon terhadap kendala yang dijumpai serta memberikan kritik dan saran yang sifatnya membangun. Angket ini diberikan pada saat guru PAUD melakukan evaluasi terhadap model pelatihan yang dikembangkan.

Perlakuan dalam penelitian ini yakni intervensi dalam bentuk Pelatihan Pengelolaan Emosi Anak Usia Dini yang disusun untuk guru atau pendidik PAUD dalam membantu anak usia dini mengelola emosi. Pengelolaan emosi yang dimaksud dalam penelitian ini adalah stimulasi atau pemberian rangsangan melalui aktivitas bermain untuk mengoptimalkan perkembangan aspek emosi anak usia dini. Adapun indikator atau karakteristik kemampuan yang hendaknya dicapai oleh anak antara lain: mengenal atau merasakan emosi sendiri, mengelola emosi, mengekspresikan emosi berdasarkan perasaan anak, serta menunjukkan rasa empati.

Pelatihan dilaksanakan dalam tiga tahap pertemuan dengan durasi waktu tiap pertemuan selama 120 menit. Selama pelatihan subjek diberikan materi tentang konsep dasar perkembangan emosi Anak Usia Dini (AUD), permasalahan emosi AUD dan strategi pengembangan emosi AUD yang dikemas dalam berbagai bentuk aktivitas dan permainan untuk menstimulasi aspek pengembangan emosi AUD. Selain itu, materi juga diselingi dengan pelaksanaan ice breaking pada setiap sesi pelatihan.

Analisis data kualitatif dilakukan dengan pendekatan deskriptif dengan menghimpun data tentang pengamatan pada lokasi penelitian, meliputi: kondisi guru, perangkat 
pembelajaran, sarana dan prasarana TK, kondisi fisik area belajar anak, serta faktor pendukung lainnya termasuk kualitas guru terkhusus dalam hal pengelolaan emosi anak. Data kuantitatif dihasilkan dengan cara menganalisis instrument penelitian dengan menggunakan statistic deskriptif persentase. Khabibah (2006) menyatakan bahwa penentuan kategori respon atau tanggapan yang diberikan guru terhadap suatu kriteria dengan mencocokkan hasil persentase dengan kriteria positif.

\section{HASIL DAN PEMBAHASAN}

Analisis respon guru yang dilaksanakan pada Pelatihan Pengelolaan Emosi AUD dinilai melalui content validity dan (empirical validity).

\section{Validasi Isi (content validity)}

Angket respon guru (ARG) sebagai instrument yang digunakan divalidasi oleh dua orang ahli.

Tabel 1. Hasil validasi instrument angket repson guru

\begin{tabular}{|c|c|c|c|c|c|}
\hline \multirow[b]{2}{*}{ No } & \multirow{2}{*}{ Aspek Penilaian } & \multicolumn{2}{|c|}{$\begin{array}{c}\text { Tim } \\
\text { Validator }\end{array}$} & \multirow[t]{2}{*}{$\mathbf{K i}$} & \multirow[t]{2}{*}{ Ket } \\
\hline & & V1 & $\mathbf{V 2}$ & & \\
\hline \multirow{4}{*}{1} & Aspek Petunjuk & & & & \\
\hline & $\begin{array}{l}\text { a. Petunjuk lembar ARG dinyatakan jelas terhadap } \\
\text { pengembangan model pengelolaan emosi anak }\end{array}$ & 4 & 4 & 4.00 & SV \\
\hline & b. Kriteria penilaian dianggap jelas & 4 & 4 & 4.00 & SV \\
\hline & Rata-rata tiap aspek (Ai) & & & 4.00 & SV \\
\hline \multirow{4}{*}{2} & Aspek yang direspon & & & & \\
\hline & a.Modul Fasilitator Pelatihan & 4 & 4 & 4 & SV \\
\hline & b. Modul Peserta Pelatihan & 3 & 4 & 3.5 & SV \\
\hline & Rata-rata tiap aspek (Ai) & & & 3.75 & SV \\
\hline \multirow{5}{*}{3} & Aspek Bahasa & & & & \\
\hline & a. Menggunakan bahasa Indonesia (sesuai dengan kaidah) & 3 & 3 & 3 & V \\
\hline & b. Rumusan pertanyaan komunitas & 2 & 4 & 3 & $\mathrm{~V}$ \\
\hline & c. Menggunakan kalimat yang mudah dipahami & 3 & 4 & 3.5 & SV \\
\hline & Rata-rata (Ai) & & & 3.17 & $\mathrm{~V}$ \\
\hline & Rata-rata total (x) & & & 3.64 & SV \\
\hline
\end{tabular}

Hasil validasi ARG pada tabel 2 untuk aspek petunjuk memperoleh nilai $x=4,00$. Berdasarkan nilai kevalidan, maka nilai rata-rata aspek berada pada $4>\mathrm{R}>3,5$, sehingga dikategorikan sangat valid. Ditinjau dari aspek yang direspon memperoleh nilai $x=3,75$. Berdasarkan nilai kevalidan, maka nilai rata-rata aspek berada pada $4>\mathrm{R}>3,5$, sehingga dikategorikan sangat valid. Dan dari aspek bahasa diperoleh nilai $x=3,17$. Berdasarkan nilai kevalidan, maka nilai rata-rata aspek bahasa berada pada 3,5>R $>2,5$, sehingga dikategorikan valid. 
Adapun total rata-rata keseluruhan aspek pada angket reson guru $x=3,64$. Instrumen Angket Respon Guru masuk dalam kategori sangat valid, karena berada pada rentang 4> $M>3,5$. Artinya instrumen ARG dapat dinyatakan memenuhi kriteria kevalidan. Koefisien reliabilitas (R) ARG dimana rata-rata derajat agreement, d $(\mathrm{A})=6$ dan rata-rata disagreement, $\mathrm{d}(\mathrm{D})=1$. Diperoleh nilai $\mathrm{R}=0,86$ berada pada rentang $0,80<\mathrm{R}<1,0$ termasuk kategori sangat tinggi. Sehingga ARG dinyatakan reliabel.

\section{Validasi Empirik}

Penilaian respon guru ini dilakukan oleh 30 orang guru TK yang menjadi peserta uji coba pelatihan pengelolaan emosi anak usia dini. Adapun hasil penilaian guru tersebut, antara lain:

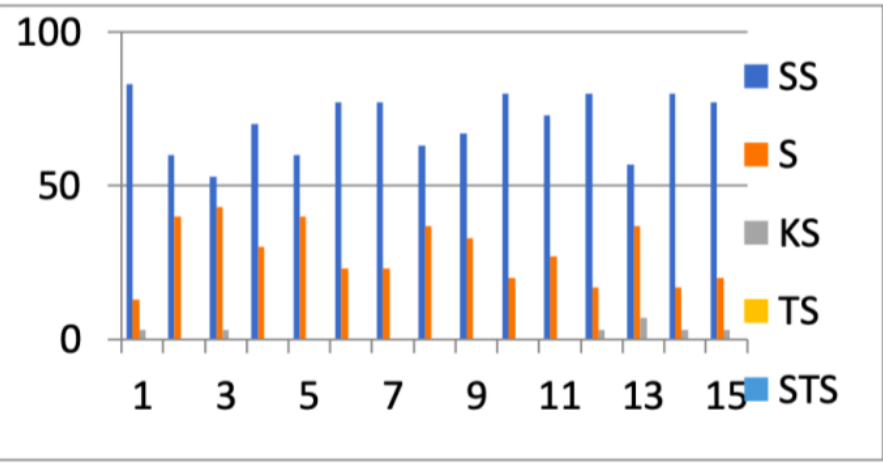

Setelah dilakukan analisis persentase, maka ditemukan hasil untuk pilihan jawaban sangat tidak setuju (STS) 0\%, jawaban tidak setuju (TS) 0\%, jawaban kurang setuju (KS) $2 \%$, jawaban setuju (S) sebanyak $28 \%$, dan $70 \%$ untuk pilihan jawaban sangat setuju (SS). Jadi hasil analisis menyatakan bahwa sebesar $98 \%$ subjek penelitian dalam hal ini guru PAUD memberi respon positif terhadap pelatihan pengelolaan emosi Anak Usia Dini.

Potensi kesuksesan anak dapat distimulasi dengan berbagai cara, salah satunya dengan mengajarkan anak usia dini mengelola emosi dengan tepat. Karena perkembangan emosi juga berkontribusi besar bagi keberhasilan anak dalam proses belajarnya. Sejak dini, aspek emosi anak sudah mulai berkembang. Ketidakmampuan anak mengelola emosinya dengan baik dapat menimbulkan permasalahan psikologis dan fisik bagi anak usia dini. Anak yang mampu mengelola emosinya dengan baik biasanya lebih terampil mengendalikan diri saat marah, mudah memahami perasaan orang lain, mudah mengatur keadaan emosinya, serta mudah menjalin hubungan dengan orang disekitarnya.

Jika merujuk pada karakteristik perkembangan anak usia dini, maka poin penting yang akan kita temukan bahwa bermain adalah bentuk aktivitas yang menjadikan anak memahami hal yang sedang mereka pelajari. Dengan demikian, penyampaian pembelajaran apapun bagi Anak Usia Dini yang sesuai dengan tingkat pencapaian perkembangannya, akan sangat memungkinkan untuk disampaikan termasuk pengembangan aspek emosi anak.

Penerapan strategi pengelolaan emosi pada anak usia dini ini memiliki panduan yang telah divalidasi oleh ahli, sehingga guru dapat menerapkannya dengan sangat baik. 
Terbukti pada pelaksanaan uji coba, guru mampu melaksanakan berbagai aktivitas yang bertujuan untuk mengembangkan aspek emosi anak.

Keefektifan pelaksanaan uji coba pengembangan model dinilai dari pengisian angket respon guru. Hasil analisis respon guru terhadap setiap pernyataan pada ARG rata-rata berada pada kategori setuju dan sangat setuju. Artinya guru memberi respon positif terhadap implementasi pelaksanaan Pelatihan Pengelolaan Emosi Anak Usia Dini

Setelah melaksanakan penelitian, ditemukan beberapa saran pengembangan untuk perbaikan penelitian kedepannya, antara lain:

a. Guru PAUD menyatakan butuh materi untuk dijadikan pedoman dalam mengelola emosi anak usia dini.

b. Antuasiasme dan dorongan dari guru PAUD yang mendukung pelaksanaan kegiatan ini. Para guru berharap supaya ada kelanjutan materi dari pelatihan yang diberikan.

c. Peran pengembangan aspek emosi anak tidak hanya berfokus pada guru PAUD saja, namun orang tua juga perlu dilibatkan untuk memahami perkembangan emosi anak. Melalui pelatihan pengelolaan emosi anak usia dini, para guru PAUD dapat membagi ilmu yang telah didapatkan kepada orang tua / wali peserta didik.

d. Area bermain di sekitar sekolah (di luar kelas) dapat dijadikan area pembelajaran yang mampu meningkatkan semangat belajar anak.

e. TK Melati Kabupaten Gowa sebagai lokasi penelitian adalah sekolah yang menerapkan sistem inklusif. Sehingga, para pendidik di sekolah tersebut membutuhkan desain model pengembangan emosi yang ditujukan kepada anak berkebutuhan khusus (ABK). Mengingat adanya perbedaan dalam penanganan ABK dengan penanganan peserta didik normal lainnya.

\section{SIMPULAN}

Penelitian ini menemukan bahwa pengelolaan emosi anak yang dilaksanakan pada lokasi penelitian menunjukkan bahwa guru atau pendidik PAUD masih merasa kesulitan dalam mengembangkan aspek emosi anak. Proses pembelajaran di dalam kelas lebih monoton terhadap pengembangan salah satu aspek perkembangan saja. Otak anak seakan dipaksa untuk mengingat berbagai informasi. Namun pembelajaran yang diterapkan masih kurang mampu menjadikan anak untuk mampu mengelola emosinya sendiri. Oleh karena itu dibutuhkan bimbingan dari guru atau pendidik PAUD agar bisa memaksimalkan pengembangan aspek emosi tersebut, melalui pelatihan pengelolaan emosi anak usia dini.Respon guru tarkait pelaksanaan Pelatihan Pengelolaan Emosi bagi Anak Usia adalah positif. Hal tersebut terlihat dari hasil validasi empiric yang memenuhi kriteria keefektifan. 


\section{DAFTAR PUSTAKA}

Angesti, F. (2020). Pentingnya Kompetensi Pedagogik Bagi Guru Pendidikan Anak Usia Dini. Jurnal CARE (Children Advisory Research and Education), 7(2), 43-48.

Astinah, A., Wahyuningsih, H., \& Rachmahana, R. S. A. (2019). Pelatihan Emotion Coaching Untuk Meningkatkan Ketrampilan Guru Merespon Emosi Anak Usia Dini. JIP (Jurnal Intervensi Psikologi), 11(2), 67-78.

Fasli, J. 2005. Strategi Peningkatan Mutu Pendidikan dan Tenaga Kependidikan PAUD. Makalah Seminar dan Lokakarya Nasional PAUD. Yogyakarta: Dirjen PLS Depniknas dan UGM.

Goleman, D., \& Boyatzis, R. (2017). Emotional intelligence has 12 elements. Which do you need to work on. Harvard Business Review, 84(2), 1-5.

Maharani, E. A. (2017). Analisis komparatif faktor penyebab dan tingkat stres guru PAUD selama menjalani tugas belajar strata-1 (S1). On Indonesian Islam, Education And Science (ICIIES) 2017, 437.

Maryatun, I. B. (2016). Peran pendidik PAUD dalam membangun Karakter Anak. Jurnal Pendidikan Anak, 5(1).

Mashar, R. (2015). Emosi anak usia dini dan strategi pengembangannya. Kencana.

Sudrajat, A. 2008. Pelatihan dalam Rangka Pengembangan Profesi Guru. (Online) (https://akhmadsudrajat.wordpress.com), [15 September 2020].

Sugiyono, P. D. (2019). Metode Penelitian Pendidikan: Kuantitatif, Kualitatif, Kombinasi, R\&D dan Penelitian Pendidikan (Cetakan Ke 1). Bandung: CV Alfabeta.

Sumitra, A., \& Sumini, N. (2019). Peran Guru dalam Mengembangkan Kemampuan Minat Baca Anak Usia Dini Melalui Metode Read Aloud. Jurnal Ilmiah Potensia, 4(2), 115120

Wijaya, I. (2018).Professional Teacher: Menjadi Guru Profesional. CV Jejak (Jejak Publisher). 